Original Research Paper

\title{
The Effects of Costus Root Aqueous Extract against Schistosomiasis, Liver Damage and Oxidants in Mouse Models of Schistosoma mansoni Infection
}

\author{
Areej Jameel M. Alghabban \\ Department of Biology, Faculty of Science, University of Tabuk, KSA
}

\section{Article history}

Received: 19-01-2021

Revised: 03-04-2021

Accepted: 06-04-2021

Email: a_alghabban@ut.edu.sa

\begin{abstract}
Schistosomiasis is one of the major human parasitic diseases in many developing countries that causing chronic ill health in humans. The present work aimed to study the possible curative role of Costus (Saussurea lappa) root extract against Schistosoma mansoni infection induced liver toxicity, cytokines, oxidative stress and DNA damage in mice. 40 adult male micewere divided into four groups (G1, control; G2, Costus; G3, infection with $S$. mansoni live cercariae; G4, S. mansoni infection followed by Costus treatment). By comparison to control, mice with $S$. mansoni infection exhibited significantly $(p<0.01)$ higher levels of plasma TNF- $\alpha$, faecal and hepatic eggs load, hepatic DNA damage and MDA, as well as significantly $(p<0.01)$ lower levels of hepatic GSH, catalase and SOD. Meanwhile, by comparison to mice with $S$. mansoni infection, infected mice treated with Costus root extract had significantly $(p<0.01)$ lower levels of faecal and hepatic eggs load, granuloma diameter, TNF- $\alpha$ in plasma, hepatic MDA, DNA damage, as well as significantly higher levels of hepatic GSH, catalase and SOD. The conclusion derived was that free radicals are formed by the host-parasite interaction because the parasite induces alterations in the hepatic antioxidants of the host to be able to scavenge the radicals as oxidative stress makes it difficult for the parasite to overpower the host's immune response.
\end{abstract}

Keywords: Schistosomiasis, Costus Root Extract, Granuloma, Cytokines, Oxidative Stress, DNA Damage, Mice

\section{Introduction}

Numerous developing nations are confronted with significant public health issues caused by schistosomiasis, resulting in morbidity and mortality and thus having socio-economic implications (Andrade, 2004; Tousson et al., 2013; Alghabban, 2014). Schistosoma trematodes are the parasites that cause schistosomiasis. The main symptoms of Schistosoma mansoni infection are anaemia, abdominal pain and impaired mental and physical development. It affects more than 200 million individuals across 74 countries, with annual infection rate of up to 200,000 individuals. Chronic infection of high severity can result in hepatomegaly, splenomegaly, hepatic fibrosis and/or cancer, with an annual mortality rate of up to 20,000 individuals (Farias et al., 2010; Lamberton et al., 2017). Schistosomiasis can be managed through a strategy integrating chemotherapy, health education and snail control. Initiatives of schistosomiasis management are still highly dependent on chemotherapy because a vaccine of proven efficiency and safety is yet to be developed (Helmy et al., 2009).

Natural plant-based products are considered to contain an abundance of compounds with therapeutic potential and they are extensively used throughout the world due to the perception of safety and powerful antioxidant effects (Al-Rasheed et al., 2018; El-Masry et al., 2018; Tousson et al., 2014; 2016; 2018; Alotaibi et al., 2020; 2021; Altwaijry et al., 2020; Abd Eldaimet al., 2021). Endogenous to northern India and Pakistan, the plant Saussureacostus figures prominently in Chinese and Indian traditional medicine (Tousson et al., 2020a). With high levels of antioxidants, Costus is used to treat a wide range of conditions, such as diarrhoea, nausea, tenesmus, stomach pain, dyspepsia, vomiting, 
inflammation and bronchitis (Irshad et al., 2012; Abd Eldaim et al., 2019a).

It has even been claimed that Costus extract can be employed to treat conditions like cholera and typhoid as well as to eradicate intestinal parasites (e.g., roundworms). Assessment of Costus for a range of pharmacological effects has revealed that it has renal activity against oxidants (Tousson et al., 2020a), hepatotoxicity (Tousson et al., 2019), fungi (Barrero et al., 2000), parasitic worms (helminths) (Seki et al., 1991), inflammation (Sunkara et al., 2010) and microbes (Abeysinghe, 2010) as well as that it stimulates immunity (Hamilton, 2004).

Therefore, the present work has been planned to study the curative role of Costus (Saussurea lappa) root extractagainst Schistosoma mansoni infection induced improvement in liver toxicity, cytokines, oxidative stress and DNA damage in mice.

\section{Materials and Methods}

\section{Chemical Compounds}

Robertet Inc. (France) provided the Saussurea lappa absolute.

\section{Experimental Animals}

The Schistosome Biological Supply Centre (SBSC) of the Theodor Bilharz Research Institute (TBRI) in Giza, Egypt, supplied the MC1-strain Swiss albino mice of male sex and with a weight of $23 \pm 2 \mathrm{~g}$. They were kept under laboratory conditions, at a temperature of $21^{\circ} \mathrm{C}$ and without food and water restrictions.

Infected Biomophalaria alexandrina snails grown in the laboratory were the source of $S$. mansoni cercariae. In keeping with Peters and Warren (1969), infection of the mice was achieved by introducing their tails into a suspension containing 60-65 cercariae in particular tubes for half an hour.

A total of 40 mice were equally divided into four groups (10 mice each). The first group (G1) represented the control group included mice received no treatment; the second group (G2) represented the costus group included mice received by oral gavages Costus extract at a dose of (50 mg/Kg body weight/2day) for four weeks (Abd Eldaim et al., 2019b); the third group (G3) comprised mice with infection with $60 \mathrm{~S}$. mansoni live cercariae for a period of eight weeks (Tousson et al., 2013); the fourth group (G4) comprised mice with infection with $60 \mathrm{~S}$. mansoni live cercariae for a period of eight weeks followed by treatment with $50 \mathrm{mg} / \mathrm{kg}$ body weight/2day Costus extract for a further four weeks:

At the end of treatment period, all mice from each group were sacrificed, where the blood and the liver of each animal were collected immediately and labelled. After $10 \mathrm{~min}$ incubation at ambient temperature, the blood was allowed to coagulate before being subjected to 3000-rpm centrifugation.

Whilst awaiting biochemical and molecular analysis, sera were stored at $-20^{\circ} \mathrm{C}$. Weighing and measurement of the extracted livers were conducted as well. Ice-cold saline was used to wash the livers thrice to eliminate unnecessary tissue and subsequently the livers were left to chill on ice. The livers were then cut into four segments that were enclosed in aluminium foil and kept at $-80^{\circ} \mathrm{C}$ until needed to prepare tissue homogenates.

\section{Measurement of Tumour Necrosis Factor Alpha}

According to the manufacturer's guidelines, monoclonal antibodies with specificity for Tumour Necrosis Factor alpha (TNF- $\alpha$ ) were employed to conduct a quantitative sandwich enzyme immunoassay (R\&D systems, Minneapolis, USA).

\section{Measurement of Granulomas}

Paraffin blocks were produced through fixation in $10 \%$ of neutral buffered formalin and processing of a liver specimen from every mouse. After they were divided into segments of $5 \mu \mathrm{m}$, the blocks were subjected to staining with Ehrlich's haematoxylin and eosin counter-staining (Tousson, 2016).

The diameter of the granulomas encircling one Schistosoma egg was measured with an ocular micrometre. An Olympus microscope was used to take micrographs, while a digital camera (Cannon 620) facilitated the capture of images. 40-50 granulomas were used to determine the mean granuloma diameter.

\section{Measurement of the Number of Eggs in Faeces and Liver}

Faces were weighed, homogenized in $10 \%$ buffered formaldehyde and stored at $4^{\circ} \mathrm{C}$. Two aliquots of $100 \mu \mathrm{L}$ each were counted on light microscope. The liver was cleaned, weighed and digested in $4 \% \mathrm{KOH}$ solution at $37^{\circ} \mathrm{C}$ for $6 \mathrm{~h}$. The digested tissue suspensions were subjected to five-minute centrifugation at $1500 \mathrm{rpm}$, with elimination of supernatants.

The eggs were counted in the two $100 \mu \mathrm{L}$ aliquots under a light microscope following repetition of the washing and centrifugation steps three times. The expression of the measurement took the form of the mean egg count for each gram of faeces or of hepatic tissues.

\section{Tissue Preparation}

Ice-cold $1.15 \%$ potassium chloride and $0.01 \mathrm{~mol} / \mathrm{l}$ sodium potassium phosphate buffer with $\mathrm{pH} 7.4$ were used for homogenisation of hepatic tissues in a homogeniser of Potter-Elvehjem type, yielding $10 \%$ w/v homogenisation. 
The homogenate was subjected to $20 \mathrm{~min}$ centrifugation at $4{ }^{\circ} \mathrm{C}$ and $10,000 \mathrm{~g}$, with the supernatant obtained in this way being employed for enzyme assays.

\section{Measurement of Oxidative Stress Biomarkers}

The procedure suggested by (Saggu et al., 2014) was applied to measure Thiobarbituric Acid-Reactive Substances (TBARS) in liver homogenate. Catalase (CAT; EC 1.11.1.6) enzymatic activity in liver homogenate was determined via the procedure of (Aebi, 1984), reduced Glutathione (GSH) content in liver homogenate was determined via the procedure of (Aldubayan et al., 2019), while superoxide dismutase enzymatic activity (SOD; EC 1.15.1.1) in liver homogenate was determined via the procedure by (Misra and Fridovich, 1972).

\section{Measurement of Hepatic DNA Damage Via Comet Assay}

In accordance with (Abd Eldaim et al., 2019a), the comet assay (single-cell gel electrophoresis) was performed to assess hepatic DNA damage (Tousson et al., 2020b).

\section{Statistical Analysis}

One-way ANOVA was applied to conduct statistical analysis and identify inter-group differences of significance. Expression of data took the form of mean values $\pm \mathrm{SE}$ and a $p$ value of less than 0.01 was considered statistically significant.

\section{Results}

\section{The Activity of Costus Root Extract on Egg Count}

Figure 1 revealed a significant $(\mathrm{p}<0.01)$ reduction of eggs load in the feces and in the liver after the treatment of infected mice with Costus root extract as compared to infected mice with schistosoma.

\section{The Activity of Costus Root Extract on Granuloma Diameter}

Treatment of infected mice with Costus extract revealed a significant $(p<0.01)$ reduction in granuloma diameter as compared with schistosoma infected mice (Table 1).

\section{The Activity of Costus Extract on TNF- $\alpha$ Marker}

By comparison to control, mice with $S$. mansoni infection displayed significantly $(p<0.01)$ higher levels of TNF- $\alpha$ in plasma (Table 1). By contrast, infected mice treated with Costus extract had significantly lower plasma TNF- $\alpha$ than untreated infected mice (Table 1).

\section{The Activity of Costus Extract on Oxidative Stress Markers}

Hepatic MDA levels were significantly $(p<0.01)$ higher while hepatic GSH, catalase and SOD levels were significantly $(p<0.01)$ reduced inmice with $S$. mansoni infection than in the control and Costus groups (Fig. 2). By contrast, treatment of infected mice with Costus for 4 weeks revealed a significant $(P<0.01)$ increased in the levels of CAT, GSH and SOD and a significant $(P<0.01)$ decrease in the level of MDA in liver tissue as compared with infected group (Fig. 2).

\section{The Activity of Costus Extract on Hepatic DNA Damage}

Hepatic DNA damage in mice with $S$. mansoni infection and the effect of Costus root extract on mice with infection were both investigated via a comet assay (Fig. 3). By comparison to the control and Costus groups, mice with $S$. mansoni infection displayed more marked hepatic DNA damage $(p<0.05)$, as reflected by tail lengthening and increase in tail DNA\% and tail moment. However, this marked DNA damage was significantly decreased in infected mice treated with Costus as compared to the mice with $S$. mansoni infection (Table 2 and Fig. 3 ).

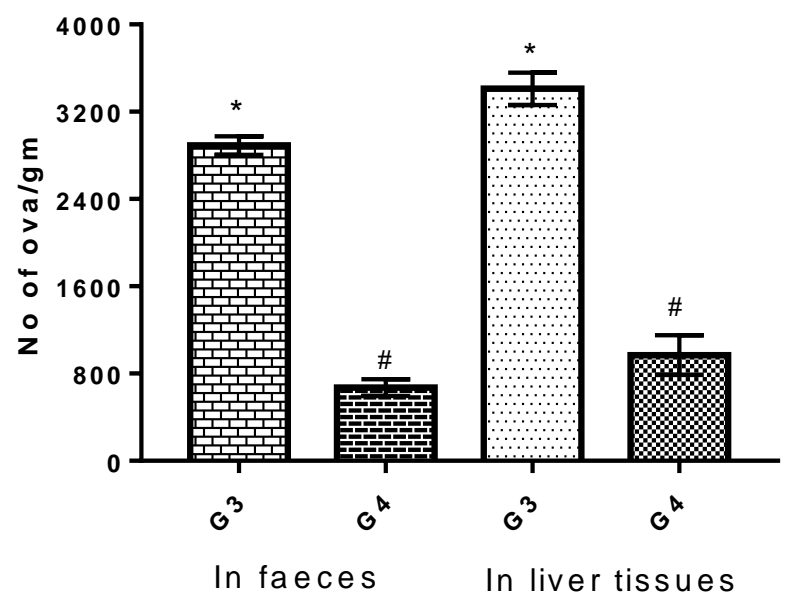

Fig. 1: The diminished egg count in faeces and liver elicited by Costus administration to mice with S. mansoniinfection 

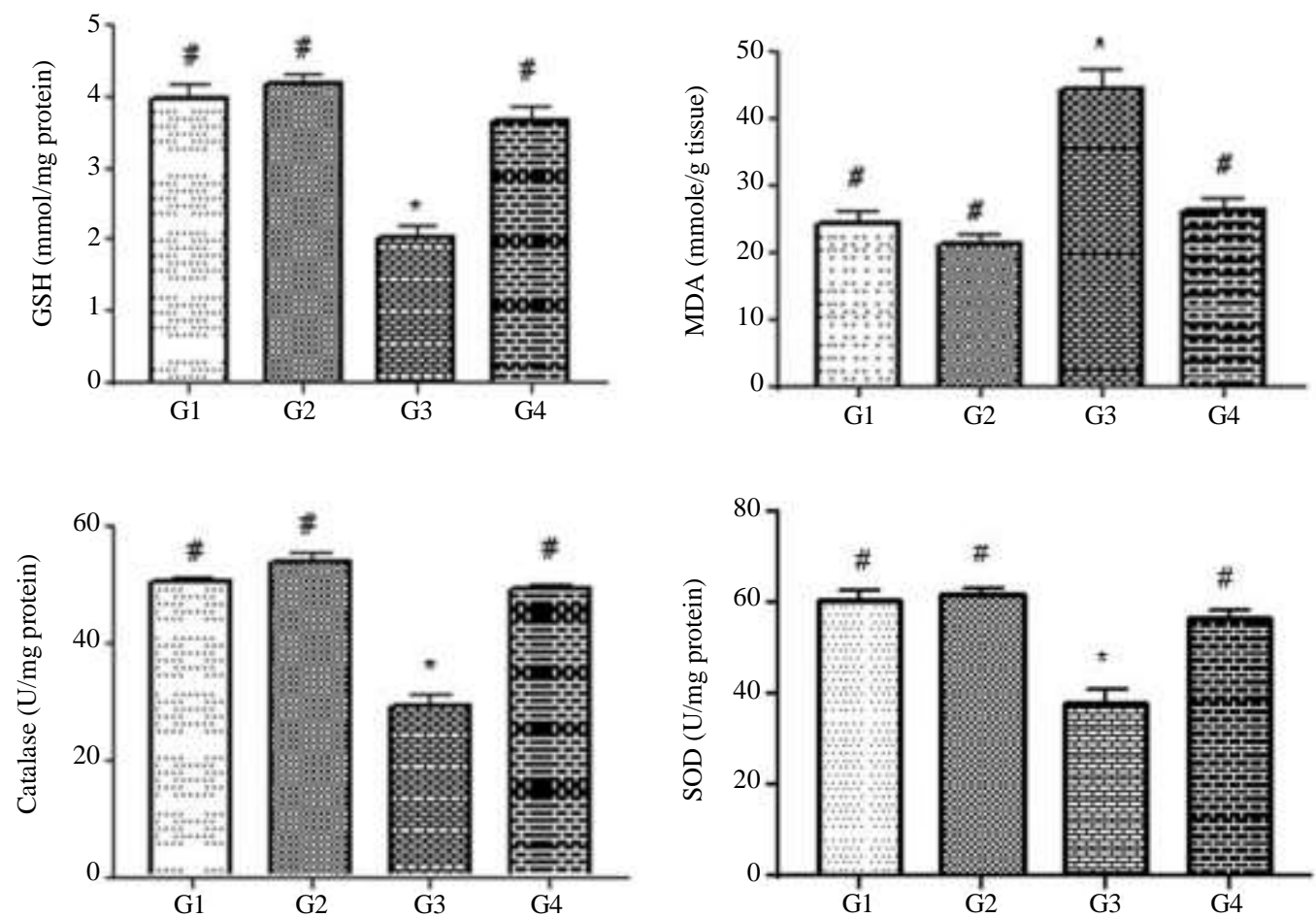

Fig. 2: Changes in MDA (nmole/g tissue), Glutathione content (GSH; mmol/mg protein), Catalase (CAT; U/mg protein) and Superoxide Dismutase (SOD; U/mg protein) levels in liver tissues in different experimental groups. Expression of values takes the form of means $\pm \mathrm{SE}$, with $\mathrm{n}=5$ for every experimental group. $\mathrm{G} 1=$ control, $\mathrm{G} 2=$ Costus group, $\mathrm{G} 3=$ infected group, $\mathrm{G} 4=\mathrm{infected}$ group with Costus treatment. \# and * respectively denote difference of significance from G3 and from G1
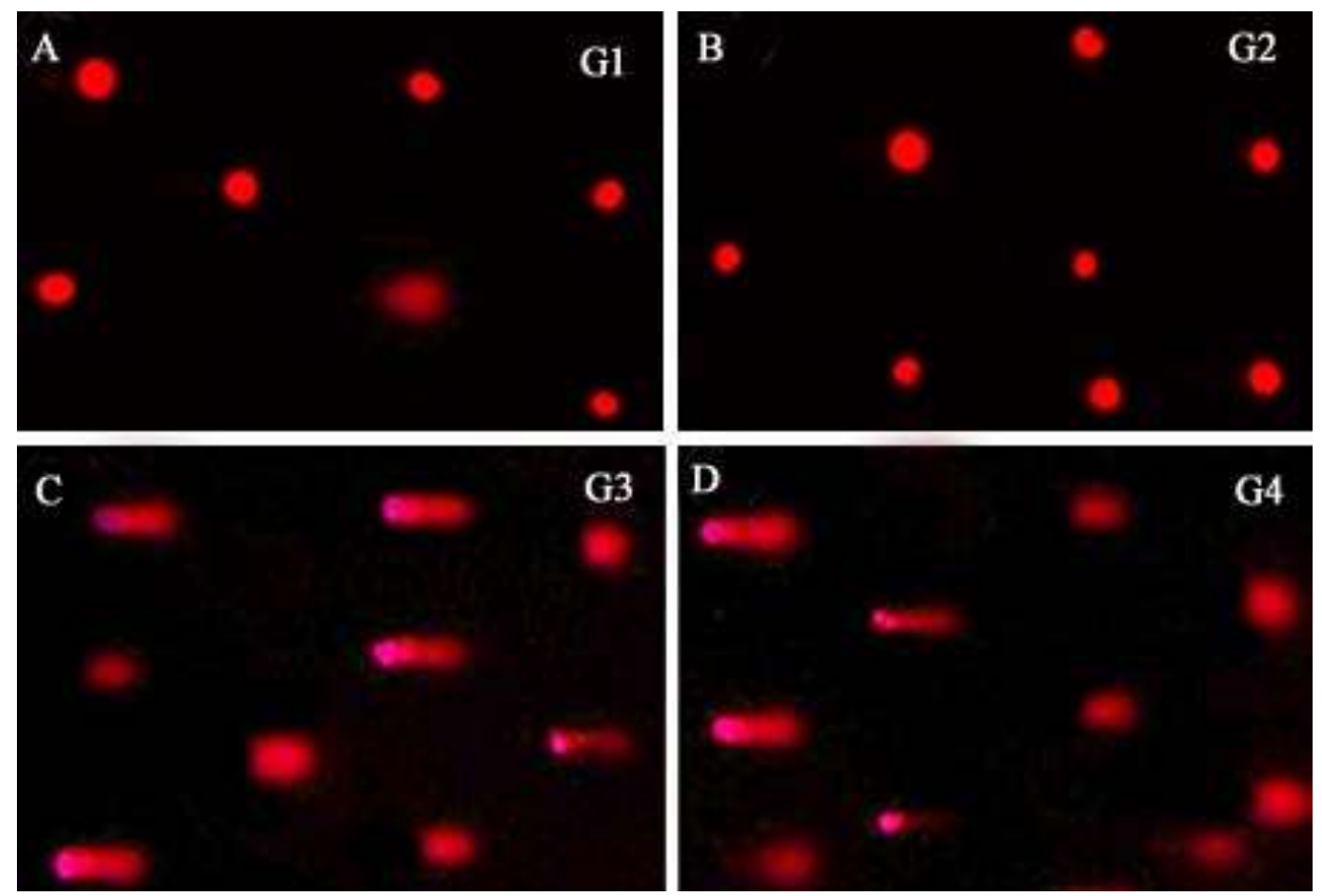

Fig. 3: Inter-group comparison of hepatic DNA damage assessed via comet assay. G1 = control, G2 = Costus group, G3 = infected group, G4 = infected group with Costus treatment 
Table 1: Changes in plasma TNF $\alpha$ and granuloma diameter in experimental groups

\begin{tabular}{lllll}
\hline & G1 & G2 & G3 & G4 \\
\hline TNF $\alpha$ & $27.3^{\#} \pm 0.87$ & $25.1^{\#} \pm 1.15$ & $39.7^{*} \pm 1.39$ & $30.0^{\sharp} \pm 1.25$ \\
Granuloma diameter $(\mathrm{nm})$ & 0 & 0 & $381.0 \pm 12.4^{*}$ & $303.5 \pm 12.5$ \\
\hline
\end{tabular}

Expression of data takes the form of mean \pm SE of ten observations, with statistical significance denoted by $p<0.01$. G1 = control, G2 = Costus group, G3 = infected group, G4 = infected group with Costus treatment

Table 2: Hepatic DNA damage in the experimental groups determined via comet assay. Parameters derived via image analysis in cells from each group

\begin{tabular}{lllll}
\hline & G1 & G2 & G3 & G4 \\
\hline Tailed \% & 2 & 1.5 & 9 & 4 \\
Untailed \% & 98 & 98.5 & 91 & 96 \\
Tails length $\mu \mathrm{m}$ & $2.00^{\#} \pm 0.19$ & $1.71^{\#} \pm 0.22$ & $4.10^{*} \pm 0.12$ & $2.48^{* \# \pm 0.15}$ \\
Tail DNA\% & 1.80 & 1.69 & 3.15 & 2.10 \\
Tail moment & 3.55 & 2.90 & 12.60 & 5.40 \\
\hline
\end{tabular}

\#and * respectively denoted significant difference from G3 and G1. Significant difference was indicated by tail length with $p$-value of less than 0.05 .

\section{Discussion}

Schistosoma mansoni is an infection of trematodes that cause periportal fibrosis and liver cirrhosis due to deposition of eggs in the small portal venules (Lamberton et al., 2017). No other tissue or organ is more impacted by schistosomiasis than the liver (Andrade, 2004). The first host reaction to egg deposition in the liver is an immunological response to the antigens produced by the organisms within the eggs, taking the form of a granulomatous reaction (Warren, 1979).

An inflammatory chain reaction is sparked by egg deposition in the liver, with activated leukocytes, eosinophils, macrophages and Kupffer cells being mobilised in the proximity of the eggs (Andrade, 2004; Pearce, 2005; Fairfax et al., 2012). The results obtained in the present study indicated that Costus extract was effective in decreasing the diameter of granulomas as well as the number of parasitic eggs in both faeces and hepatic tissue.

The reduction of worms and the diameter of granuloma are generally correlated to the reduction of ova in the feces and tissues, since there is a positive linear relationship between the egg output and the worm burden (Riad et al., 2013). By reducing the number of S. mansoni ova in the liver and faeces, Costus root extract may attenuate hepatosplenomegaly as it diminishes the count of $S$. mansoni ova in liver and faeces. Other studies investigating extracts of medicinal plants also reported that those extracts decreased the egg load in animal models of $S$. mansoni infection (El-Ansary et al., 2007; El Shenawy et al., 2008; Miranda et al., 2012; Alghabban, 2014). Among pharmacological activities of chemical compounds, alkaloids and tannins are known to possess anthelmintic activity. Schistosomicidal activity of alkaloids has been proved by (Miranda et al., 2012) while reduction of worm motility and depression of egg output have been correlated to the presence of tannins in plants (Paolini et al., 2003). Reduction of worm and egg load was also found by many authors after treatment of S. mansoni-infected animals with medicinal plants extracts (El-Ansary et al., 2007; El Shenawy et al., 2008; Riad et al., 2013; Miranda et al., 2012). Among pharmacological activities of chemical compounds, alkaloids and tannins are known to possess anthelmintic activity. Alkaloids present in the methanolic fraction of C. umbellatum could act as praziquantel by inducing schistosoma mortality through general paralysis or proteolysis (Doenhoff et al., 2008).

Cell apoptosis and survival, inflammation and immune response are among the processes that occur with the critical involvement of the multifunctional cytokine TNF$\alpha$ (van Horssen et al., 2006; El-Masry et al., 2020). The findings obtained by the present study pointed to the fact that, by comparison to the control, the mice with $S$. mansoni infection had significantly higher levels of TNF$\alpha$ in the plasma, which could be due to the stimulation of lipid peroxidation induced by the fact that macrophages produced more Reactive Oxygen Species (ROS).

These results are in accordance with (Warren et al., 2009) cite the exceptionally pleiotropic cytokine TNF (tumour necrosis factor) as playing a key part in the host's immune defence, inflammation and homeostasis. The results of the present study revealed notably enhanced levels of plasma TNF- $\alpha$ in the infected with schistosoma group relative to the control group, in complete agreement with a previous study by (Aldubayan et al., 2019).

This result may be ascribed to the enhanced macrophage production of reactive oxygen species which, according to (Hoek and Pastorino, 2002), promote lipid peroxidation and are believed to be important contributors to the pathogenesis of liver damage. Therefore, it is likely that the activity that Costus root extract has against oxidants contributes to the inhibiting effect of Costus on granuloma development and the decrease in the count of ova in faeces and hepatic tissues. 
The potential of DNA damaging agents was reflected in the heterogeneity of distribution of DNA corresponding to single-stranded breaks or doublestranded breaks (Ostling and Johanson, 1987). However, the application of "Comet assay" technique was essentially helpful to detect division of DNA during mitotic division in liver. The findings of the present study revealed that, by comparison to the control and Costus groups, the mice with $S$. mansoni infection exhibited significantly marked $(p<0.05)$ DNA damage in the hepatic tissues. By contrast, the heightened DNA damage was significantly decreased in infected mice treated with Costus. These results are in accordance with (Zhou et al., 2009) who argued that the apoptotic pathway of schistosomes did not differ much from the pathway of higher organisms, as deduced from genomic research. In addition, the findings of this study are consistent with those of (Khaled et al., 2011), who observed that the count of metaphases with chromosomal abnormality was significantly heightened in spontaneous lymphocyte cultures derived from human patients with $S$. mansoni infection.

This study found that, in the case of mice with $S$. mansoni infection, alterations in antioxidant mechanisms, cytokines and apoptosis were positively correlated. As reported by many earlier studies, free radicals play a role in various conditions, including cardiovascular disease, cancer, viral infections and parasitic infections (Florence, 1995; Gharib et al., 1999; Ibrahim et al., 2011; El-Demerdash et al., 2018; Tousson et al., 2020b). The levels in which free radicals and antioxidants occur in the body depend on a number of extrinsic factors, such as toxic treatments, insufficient or excessive levels of some vitamins and compounds or infections caused by various microorganisms. As demonstrated by (La Flamme et al., 2001), in the context of schistosomiasis, hepatic damage is significantly mediated by antioxidant mechanisms, as reactive oxygen intermediates are produced in greater quantity. In the current study; a significant increase in MDA and decrease in GSH, catalase and SOD in infected liver tissues in schistosoma group. It was reported in this study that Costus root extract has the ability to modulate the activities of antioxidant enzymes by increasing the levels of SOD, GSH and catalase and reducing the level of malondialdhyde.

As reported by (Parola et al., 1996), deposition of collagen in Schistosoma infections and MDA production by liver cells are positively correlated. El-Rigal et al. (2011) suggested that the intensified production of superoxide radicals by the macrophages of liver granulomas in $S$. mansoni infection might be the reason for the heightened MDA levels. Meanwhile, using hamster models of S. hematobium infection, (Sheweita et al., 2003) indicated that glutathione levels were reduced while lipid peroxides were elevated in various hamster organs, suggesting that organs become damaged in the presence of heightened levels of free radicals.

Our results agree with (Gharib et al., 1999) who confirmed that superoxide dismutase, catalase and glutathione peroxidase activities were decreased in livers of mice infected with $S$. mansoni. Also with the results of (Shaheen et al., 1994), who observed that mice with $S$. mansoni infection had higher SOD levels in the liver. Meanwhile, (Sanz et al., 1996) notably found that the elevation in SOD and reduction in GSH were due to the intensified hepatic function of cell protective mechanisms against the toxic effects of oxidants, inhibiting oxidative imbalance. Similarly, the findings obtained by (Gharib et al., 1999) indicated that catalase undertook the detoxification of hydrogen peroxide generated by peroxide dismutation, reducing its activity. In the event of superoxide overproduction, cellular damage may occur due to the reduction in SOD activity.

As endogenous antioxidants involved in cellular antioxidant protective mechanisms, catalase and glutathione are reduced when free radicals proliferate, leading to heightened cellular damage (El Shenawy et al., 2008; El-Rigal et al., 2011). Inflammatory cells discharge eosinophil peroxidase and its substrate hydrogen peroxide in the proximity of parasitic eggs (Hanna et al., 2005). According to (El-Marzouki and Amin, 1997), such transformations occur because parasitic worms in the process of development are present, because egg deposition starts, as well as because of the discharge of a number of metabolites by the parasites that target the liver tissue of the host. In the present study, the findings suggested that, by comparison to untreated mice with $S$. mansoni infection, the infected mice treated with Costus root extract exhibited a decrease in the levels of plasma TNF- $\alpha$, egg count in faeces and hepatic tissue and hepatic DNA damage, as well as heightened levels of GSH, catalase and SOD in the liver.

\section{Conclusion}

Infections of mice with $S$. mansoni induced significantly increase in the levels of plasma TNF- $\alpha$, faecal and hepatic eggs load, hepatic DNA damage and MDA, as well as significant decrease the levels of hepatic GSH, catalase and SOD. Treatments of infected mice with costus root extract induce improvements in these parameters.

\section{Funding Information}

There is no financial support received for this research.

\section{Ethics}

This article is original and contains unpublished material. The corresponding author confirms that have 
read and approved the manuscript and no ethical issues involved.

\section{References}

Abd Eldaim, M. A., Tousson, E., El Sayed, I. E. T., \& Awd, W. M. (2019a). Ameliorative effects of Saussurea lappa root aqueous extract against Ethephon-induced reproductive toxicity in male rats. Environmental Toxicology, 34(2), 150-159. https://doi.org/10.1002/tox.22669

Abd Eldaim, M. A., Tousson, E., El Sayed, I. E. T., Abd El, A. E. A. H., \& Elsharkawy, H. N. (2019b). Grape seeds proanthocyanidin extract ameliorates Ehrlich solid tumor induced renal tissue and DNA damage in mice. Biomedicine \& Pharmacotherapy, 115, 108908. https://doi.org/10.1016/j.biopha.2019.108908

Abd Eldaim, M. A., Tousson, E., El Sayed, I. E. T., Abd Elmaksoud, A. Z., \& Ahmed, A. A. (2021). Ameliorative effects of 9-diaminoacridine derivative against Ehrlich ascites carcinoma-induced hepatorenal injury in mice. Environmental Science and Pollution Research, 1-16. https://doi.org/10.1007/s11356-020-11857-y

Abeysinghe, P. D. (2010). Antibacterial activity of some medicinal mangroves against antibiotic resistant pathogenic bacteria. Indian Journal of Pharmaceutical Sciences, 72(2), 167. https://doi.org/10.4103/0250-474X.65019

Aebi, H. (1984). [13] Catalase in vitro. Methods in Enzymology, 105, 121-126. https://doi.org/10.1016/S0076-6879(84)05016-3

Aldubayan, M. A., Elgharabawy, R. M., Ahmed, A. S., \& Tousson, E. (2019). Antineoplastic activity and curative role of avenanthramides against the growth of ehrlich solid tumors in mice. Oxidative Medicine and Cellular Longevity, 2019. https://doi.org/10.1155/2019/5162687

Alghabban, A. J. (2014). Garlic treatment reduces granuloma and p53 expression in experimental schistosomiasis. International Journal Life Science, 3(1), 5-10. http://www.crdeepjournal.org/wpcontent/uploads/2014/01/Vol-3-1-2-IJLS.pdf

Alotaibi, B., Tousson, E., El-Masry, T. A., Altwaijry, N., \& Saleh, A. (2021). Ehrlich ascites carcinoma as model for studying the cardiac protective effects of curcumin nanoparticles against cardiac damage in female mice. Environmental Toxicology, 36(1), 105-113. https://doi.org/10.1002/tox.23016

Alotaibi, B., El-Masry, T. A., Tousson, E., Alarfaj, S. J., \& Saleh, A. (2020). Therapeutic effect of rocket seeds (Eruca sativa L.) against hydroxyapatite nanoparticles injection induced cardiac toxicity in rats. Pakistan Jounal Pharm. Science, 33(4), 1839-1845. https://doi.org/10.36721/PJPS.2020.33.4.SUP.18391845.1
Al-Rasheed, N. M., El-Masry, T. A., Tousson, E., Hassan, H. M., \& Al-Ghadeer, A. (2018). Hepatic protective effect of grape seed proanthocyanidin extract against Gleevec-induced apoptosis, liver Injury and Ki67 alterations in rats. Brazilian Journal of Pharmaceutical Sciences, 54(2). https://doi.org/10.1590/s2175-97902018000217391

Altwaijry, N., El-Masry, T. A., Alotaibi, B., Tousson, E., $\&$ Saleh, A. (2020). Therapeutic effects of rocket seeds (Eruca sativa L.) against testicular toxicity and oxidative stress caused by silver nanoparticles injection in rats. Environmental Toxicology, 35(9), 952-960. https://doi.org/10.1002/tox.22931

Andrade, Z. A. (2004). Schistosomal hepatopathy. Memórias do Instituto Oswaldo Cruz, 99, 51-57. https://doi.org/10.1590/S0074-02762004000900009

Barrero, A. F., Oltra, J. E., Álvarez, M., Raslan, D. S., Saúde, D. A., \& Akssira, M. (2000). New sources and antifungal activity of sesquiterpene lactones. Fitoterapia, 71(1), 60-64 https://doi.org/10.1016/S0367-326X(99)00122-7

Doenhoff, M. J., Cioli, D., \& Utzinger, J. (2008). Praziquantel: mechanisms of action, resistance and new derivatives for schistosomiasis. Current Opinion in Infectious Diseases, 21(6), 659-667. https://doi.org/10.1097/QCO.0b013e328318978f

El Shenawy, N. S., Soliman, M. F., \& Reyad, S. I. (2008). The effect of antioxidant properties of aqueous garlic extract and Nigella sativa as antischistosomiasis agents in mice. Revista do Instituto de Medicina Tropical de São Paulo, 50(1), 29-36. https://doi.org/10.1590/S0036-46652008000100007

El-Ansary, A. K., Ahmed, S. A., \& Aly, S. A. (2007). Antischistosomal and liver protective effects of Curcuma longa extract in Schistosoma mansoni infected mice. http://nopr.niscair.res.in/handle/123456789/5319

El-Demerdash, F.M., Tousson, E. M., Kurzepa, J., \& Habib, S. L. (2018). Xenobiotics, oxidative stress and antioxidants.Oxidative Medicine and Cellular Longevity. https://doi.org/10.1155/2018/9758951

El-Marzouki, Z. M., \& Amin, A. M. (1997). Changes in serum lipids of mice experimentally infected with Schistosoma mansoni. Journal of the Egyptian Society of Parasitology, 27(2), 419-429. https://europepmc.org/article/med/9257980

El-Masry, T. A., Al-Shaalan, N. H., Tousson, E., ElMorshedy, K., \& Al-Ghadeer, A. (2018). Star anise extracts modulation of reproductive parameters, fertility potential and DNA fragmentation induced by growth promoter Equigan in rat testes. Brazilian Journal of Pharmaceutical Sciences, 54(1). https://doi.org/10.1590/s2175-97902018000117261 
El-Masry, T., Al-Shaalan, N., Tousson, E., Buabeid. M. \& Al-Ghadeer, A. (2020). Potential therapy of vitamin B17 against Ehrlich solid tumor induced changes in Interferon gamma, Nuclear factor kappa $\mathrm{B}$, DNA fragmentation, $\mathrm{p} 53, \mathrm{Bcl} 2$, survivin, VEGF and TNF- $\alpha$ Expressions in mice. Pakistan. Journal of Pharmaceutical Sciences, 33(1), 393-401. https://doi.org/10.36721/PJPS.2020.33.1.SUP.393401.1

El-Rigal, N. S., Metwally, N. M., Mohamed, A. M., Mohamed, N. Z., \& Rizk, M. Z. (2011). Protection against oxidative damage induced by Schistosoma mansoni using susceptible/resistant nucleoproteins from Biomphalaria alexandrina snails. Asian Journal of Biological Sciences, 4, 445-56. https://doi.org/10.3923/ajbs.2011.445.456

Fairfax, K., Nascimento, M., Huang, S. C. C., Everts, B., \& Pearce, E. J. (2012, November). Th2 responses in schistosomiasis. In Seminars in immunopathology (Vol. 34, No. 6, pp. 863-871). Springer-Verlag. https://doi.org/10.1007/s00281-012-0354-4

Farias, L. P., Cardoso, F. C., Miyasato, P. A., Montoya, B. O., Tararam, C. A., Roffato, H. K., ... \& Leite, L. C. (2010). Schistosoma mansoni Stomatin like protein-2 is located in the tegument and induces partial protection against challenge infection. PLoSNegl Trop Dis, 4(2), e597. https://doi.org/10.1371/journal.pntd.0000597

Florence, T. M. (1995). The role of free radicals in disease. Australian and New Zealand Journal of Ophthalmology, 23(1), 3-7. https://doi.org/10.1111/j.1442-9071.1995.tb01638.x

Gharib, B., Abdallahi, O. M. S., Dessein, H., \& De Reggi, M. (1999). Development of eosinophil peroxidase activity and concomitant alteration of the antioxidant defenses in the liver of mice infected with Schistosoma mansoni. Journal of Hepatology, 30(4), 594-602. https://doi.org/10.1016/S01688278(99)80189-5

Hamilton, A. C. (2004). Medicinal plants, conservation and livelihoods. Biodiversity \& Conservation, 13(8), 1477-1517.

https://doi.org/10.1023/B:BIOC.0000021333.23413.42

Hanna, S., Gharib, B., Lepidi, H., Montet, J. C., Dumon, H., \& de Reggi, M. (2005). Experimental schistosomiasis, protective aspects of granulomatous reaction in the mouse liver. Parasitology Research, 96(1), 6-11. https://doi.org/10.1007/s00436-005-1319-5

Helmy, M. M., Mahmoud, S. S., \& Fahmy, Z. H. (2009). Schistosoma mansoni: effect of dietary zinc supplement on egg granuloma in Swiss mice treated with praziqantel. Experimental Parasitology, 122(4), 310-317. https://doi.org/10.1016/j.exppara.2009.04.006
Hoek, J. B., \& Pastorino, J. G. (2002). Ethanol, oxidative stress and cytokine-induced liver cell injury. Alcohol, 27(1), 63-68. https://doi.org/10.1016/S0741-8329(02)00215-X

Ibrahim, W., Tousson, E., Ali, E. M., \& Mansour, M. A. (2011). Folic acid alleviates oxidative stress and hyperhomocysteinemia involved in testicular dysfunction of hypothyroid rats. General and Comparative Endocrinology, 174(2), 143-149. https://doi.org/10.1016/j.ygcen.2011.08.012

Irshad, S., Mahmood, M., \& Perveen, F. (2012). In vitro antibacterial activities of three medicinal plants using agar well diffusion method. Research Journal of Biology, 2(1), 1-8.

Khaled, I. A., El-Ansary, M. S., Saleh, A. F., Mahmoud, O. M., Baioumi, E. A., \& Bakr, H. A. (2011). Cytogenetic study of the effect of Schistosoma mansoni infection on human peripheral blood lymphocytes and the role of $\beta$-carotene and vitamin $\mathrm{E}$ in modulating this effect. Molecular Biology Reports, 38(6), 4101-4109. https://doi.org/10.1007/s11033-010-0530-3

La Flamme, A. C., Patton, E. A., Bauman, B., \& Pearce, E. J. (2001). IL-4 plays a crucial role in regulating oxidative damage in the liver during schistosomiasis. The Journal of Immunology, 166(3), 1903-1911. https://doi.org/10.4049/jimmunol.166.3.1903

Lamberton, P. H., Faust, C. L., \& Webster, J. P. (2017). Praziquantel decreases fecundity in Schistosoma mansoni adult worms that survive treatment: evidence from a laboratory life-history trade-offs selection study. Infectious Diseases of Poverty, 6(1), 1-11. https://doi.org/10.1186/s40249-017-0324-0

Miranda, M. A., Magalhães, L. G., Tiossi, R. F. J., Kuehn, C. C., Oliveira, L. G. R., Rodrigues, V., ... \& Bastos, J. K. (2012). Evaluation of the schistosomicidal activity of the steroidal alkaloids from Solanum lycocarpum fruits. Parasitology Research, 111(1), 257-262. https://doi.org/10.1007/s00436-012-2827-8

Misra, H. P., \& Fridovich, I. (1972). The role of superoxide anion in the autoxidation of epinephrine and a simple assay for superoxide dismutase. Journal of Biological Chemistry, 247(10), 3170-3175. https://doi.org/10.1016/S0021-9258(19)45228-9

Ostling, O., Johanson, K. J., Blomquist, E., \& Hagelqvist, E. (1987). DNA damage in clinical radiation therapy studied by microelectrophoresis in single tumour cells. A preliminary report. Acta oncologica (Stockholm, Sweden), 26(1), 45-48. https://doi.org/10.3109/02841868709092977 
Paolini, V., Bergeaud, J. P., Grisez, C., Prevot, F., Dorchies, P., \& Hoste, H. (2003). Effects of condensed tannins on goats experimentally infected with Haemonchus contortus. Veterinary Parasitology, 113(3-4), 253-261. https://doi.org/10.1016/S0304-4017(03)00064-5

Parola, M., Leonarduzzi, G., Robino, G., Albano, E., Poli, G., \& Dianzani, M. U. (1996). On the role of lipid peroxidation in the pathogenesis of liver damage induced by long-standing cholestasis. Free Radical Biology and Medicine, 20(3), 351-359. https://doi.org/10.1016/0891-5849(96)02055-2

Pearce, E. J. (2005). Priming of the immune response by schistosome eggs. Parasite Immunology, 27(7-8), 265270. https://doi.org/10.1111/j.1365-3024.2005.00765.x

Peters, P. A., \& Warren, K. S. (1969). A rapid method of infecting mice and other laboratory animals with Schistosoma mansoni: subcutaneous injection. Journal of Parasitology, 55(3). https://doi.org/10.2307/3277297

Riad, N. H., Taha, H. A., \& Mahmoud, Y. I. (2013). Effects of garlic on Schistosoma mansoni harbored in albino mice: Molecular characterization of the host and parasite. Gene, 518(2), 287-291. https://doi.org/10.1016/j.gene.2013.01.023

Saggu, S., Sakeran, M. I., Zidan, N., Tousson, E., Mohan, A., \& Rehman, H. (2014). Ameliorating effect of chicory (Chichoriumintybus L.) fruit extract against 4-tert-octylphenol induced liver injury and oxidative stress in male rats. Food and Chemical Toxicology, 72, 138-146. https://doi.org/10.1016/j.fct.2014.06.029

Sanz, N., Díez-Fernández, C., \& Cascales, M. (1996). Variations of hepatic antioxidant systems and DNA ploidy in rats aged 2 to 8 months. Biochimica et BiophysicaActa (BBA)-Molecular Basis of Disease, 1315(2), 123-130. https://doi.org/10.1016/09254439(95)00113-1

Seki, K., Hashimoto, A., Kobayashi, H., Kawahara, Y., \& Yamahara, J. (1991). Motility inhibitory effect on Anchusan and Jintan and its active components in Anisakis type larvae. Yakuri to Chiryo, 19, 265-289.

Shaheen, A. A., \& Ebeid, F. A. (1994). Effect of praziquantel treatment on lipid peroxide levels and superoxide dismutase activity in tissues of healthy and Schistosoma mansoni infected mice. Arzneimittel-Forschung, 44(1), 94-96. https://europepmc.org/article/med/8135884

Sheweita, S. A., Mostafa, M. H., Ebid, F., \& El-Sayed, W. (2003). Changes in expression and activity of glutathione S-transferase in different organs of Schistosoma haematobium-infected hamster. Journal of biochemical and Molecular Toxicology, 17(3), 138-145. https://doi.org/10.1002/jbt.10071
Tousson, E., Beltagy, D. M., Gazia, M. A., \& AlBehbehani, B. (2013). Expressions of P53 and CD68 in mouse liver with Schistosoma mansoni infection and the protective role of silymarin. Toxicology and Industrial Health, 29(8), 761-770. https://journals.sagepub.com/doi/abs/10.1177/07482 33712442733

Tousson, E. (2016). Histopathological alterations after a growth promoter boldenone injection in rabbits. Toxicology and Industrial Health, 32(2), 299-305. https://doi.org/10.1177/0748233713500821

Tousson, E., Hafez, E., Zaki, S., \& Gad, A. (2014). P53, $\mathrm{Bcl}-2$ and $\mathrm{CD} 68$ expression in response to amethopterin-induced lung injury and ameliorating role of 1-carnitine. Biomedicine \& Pharmacotherapy, 68(5), 631-639. https://doi.org/10.1016/j.biopha.2014.05.007

Tousson, E., Hafez, E., Zaki, S., \& Gad, A. (2016). The cardioprotective effects of L-carnitine on rat cardiac injury, apoptosis and oxidative stress caused by amethopterin. Environmental Science and Pollution Research, 23(20), 20600-20608. https://doi.org/10.1007/s11356-016-7220-1

Tousson, E., Bayomy, M. F., \& Ahmed, A. A. (2018). Rosemary extract modulates fertility potential, DNA fragmentation, injury, KI67 and P53 alterations induced by etoposide in rat testes. Biomedicine \& Pharmacotherapy, 98, 769-774. https://doi.org/10.1016/j.biopha.2018.01.025

Tousson, E., ElAtrsh, A., Mansour, M., \& Abdallah, A. (2019). Modulatory effects of Saussurea lappa root aqueous extract against ethephon-induced kidney toxicity in male rats. Environmental Toxicology, 34(12), 1277-1284. https://doi.org/10.1002/tox.22828

Tousson, E., El Atrsh, A., Mansour, M., \& Abdallah, A. (2020a). Costus root aqueous extract modulates rat liver toxicity, DNA damage, injury, proliferation alterations induced by plant growth regulator Ethephon. Brazilian Journal of Pharmaceutical Science 56(1). https://doi.org/10.1590/s217597902019000318500

Tousson, E., Hafez, E., Zaki, S., Gad, A., \& Elgharabawy, R. M. (2020b). Evaluation of the testicular protection conferred by damiana (Turnera diffusa Willd.) against amitriptyline-induced testicular toxicity, DNA damage and apoptosis in rats. Biomedicine \& Pharmacotherapy, 132, 110819. https://doi.org/10.1016/j.biopha.2020.110819

van Horssen, R., Ten Hagen, T. L., \& Eggermont, A. M. (2006). TNF- $\alpha$ in cancer treatment: molecular insights, antitumor effects and clinical utility. The Oncologist, 11(4), 397-408. https://doi.org/10.1634/theoncologist.11-4-397 
Warren, K. S., \& KS, W. (1979). The pathogenesis of hepatosplenic schistosomiasis: from man to monkey to mouse to molecule. https://pascalfrancis.inist.fr/vibad/index.php?action=getRecordDe tail\&idt=PASCAL7950460117

Warren, O. J., Smith, A. J., Alexiou, C., Rogers, P. L., Jawad, N., Vincent, C., ... \& Athanasiou, T. (2009). The inflammatory response to cardiopulmonary bypass: part 1-mechanisms of pathogenesis. Journal of Cardiothoracic and Vascular Anesthesia, 23(2), 223-231. https://doi.org/10.1053/j.jvca.2008.08.007
Sunkara, Y., Robinson, A., Babu, K. S., Naidu, V. G. M., Vishnuvardhan, M. V. P. S., Ramakrishna, S., ... \& Rao, J. M. (2010). Anti-inflammatory and cytotoxic activity of chloroform extract of roots of Saussurea lappa Clarke. Journal of Pharmacy Research, 3(8), 1775-1778. https://www.cabdirect.org/cabdirect/abstract/201032 96027

Zhou, Y., Zheng, H., Chen, X., Zhang, L., Wang, K., \& Wang, S. (2009). The Schistosoma japonicum genome reveals features of host-parasite interplay. Nature, 460(7253), 345. https://doi.org/10.1038/nature08140 